\title{
Comercio y atlantización del Pacífico mexicano y sudamericano: la crisis del lago indiano y del Galeón de Manila, 1750-1821
}

\author{
Trade and Atlantization Mexican Pacific \\ and South America. The Crisis of lago indiano \\ and Manila Galleon, 1750-1821
}

\author{
Mariano Bonialian \\ El Colegio de México, Centro de Estudios Históricos, Ciudad de México, México, \\ email: marianobonialian@gmail.com
}

Resumen. El ensayo tiene por objetivo identificar los factores que contribuyeron a la crisis y desaparición de un sistema comercial que se desarrolló por el Pacífico colonial entre 1580 y 1750 . Se identifican tres razones, todas ellas ocurridas en el periodo comprendido desde 1750 hasta 1821. La primera examina la aparición a la escena de las compañías comerciales peninsulares por el Pacífico novohispano que comienzan a competir comercialmente con el Galeón de Manila. La segunda razón trata sobre el cierre del mercado de Perú al comercio de bienes extranjeros procedentes de Acapulco, a través de la inauguración de la vía por el Cabo de Hornos (1740) para el tráfico de navíos de registro procedentes de Europa. La tercera examina el comercio de los ingleses entre Jamaica, Panamá y el puerto mexicano de San Blas durante las primeras décadas del siglo XIX.

Palabras clave: comercio; Pacífico; reformas borbónicas; Cabo de Hornos; Panamá.

Abstract. The essay has to aims to identify the factors that contributed to the crisis and disappearance of a trading system that was developed by the colonial Pacific between 1580 and 1750 . They identified three reasons, all of which occurred in the period from 1750 to 1821 . The first, the appearance on the scene of the peninsular commercial companies by the Pacific novohispano begin to compete commercially with the Manila galleon under review. The second reason is about the market close Peru foreign goods trade from Acapulco, through the opening of the route around Cabo de Hornos (1740) for the registration of ships traffic from Europe. The third one examines the British trade between Jamaica, Panama and the Mexican port of San Blas in the early decades of the nineteenth century.

Key words: Trade; Pacific; bourbon reforms; Cabo de Hornos; Panama.

Artículo recibido: 19 de mayo de 2016. Artículo aceptado: 4 de julio de 2016.

Am. Lat. Hist. Econ., ene.-abr., 2017, pp. 7-36 | DOI: 10.18232/alhe.v24i1.791 


\section{Antecedentes. El Pacífico como laGo indiano (1580-1740)}

\section{$\mathrm{E}$} n investigaciones previas sugerimos que hasta 1740 el Pacífico colonial, entendido como el espacio triangular que conectaba las islas Filipinas, Nueva España occidental y las costas del occidente sudamericano, fue un verdadero lago indiano (Bonialian, 2012, pp. 145-157). Por su contenido y forma, nuestra caracterización se alejaba de la noción Spanish Lake propuesta por reconocidos estudios del campo historiográfico (Bernabeu, 1992; Romano 1998, pp. 41-49; Schurz, 1922; Spate, 1979). El lago indiano alcanzaba su justificación por una sencilla razón: los circuitos comerciales (legales o ilegales) por el espacio marítimo estuvieron promovidos, controlados y desarrollados por los grandes mercaderes de la ciudad de México y de Lima. Al investigar la red y el tejido constituido por los comerciantes implicados en el comercio por el Mar del Sur y por el eje transpacífico del Galeón de Manila percibimos que muchos de ellos formaban parte de sus respectivos consulados (Bonialian, 2012, pp. 340350). Demostramos también que los agentes económicos contaron con la complicidad de la estructura política virreinal para mantener su dominio por el área marítima, desde los virreyes hasta el funcionario costero de menor jerarquía. La identidad de los agentes que actuaban por los circuitos ya nos alertaba de lo inadecuado de referirse a un "Pacífico español" o, más aún, a la existencia de un "Pacífico europeo" (Hoberman, 1991, pp. 211-217; Yuste, 1984, p. 14). ${ }^{1}$

El convencimiento de pensar en un lago indiano se tornó más sólido cuando constatamos que los agentes comerciales hispanoamericanos operaron en clara oposición a los intereses de los cargadores peninsulares y de las arcas reales de la monarquía hispánica. Notables volúmenes de plata de Potosí y de las minas mexicanas fluyeron hacia China, esquivando los impuestos y los circuitos monopólicos trasatlánticos que tenían por destino España. La capacidad de intervención del poder real y de los comerciantes españoles sobre el lago indiano resultó, en efecto, mínima. El Galeón de Manila, que en los hechos era un verdadero galeón novohispano, sobrevivió gracias al contrabando y al comercio fuera de registro. Por el Mar del Sur, el comercio entre Acapulco y el puerto peruano de El Callao funcionó con notable dinámica, logrando que el mercado sudamericano dispusiera para su consumo de bienes asiáticos y europeos procedentes de Nueva España. La permanente e insistente legislación española pregonando por un comercio regulado en torno a la Nao de China y de una prohibición para

\footnotetext{
${ }^{1}$ Abundantes estudios ponen el acento en la presencia de piratas y corsarios ingleses y holandeses por el Pacífico, entre los siglos XVI y XVIII. No desconocemos tal fenómeno, pero fue coyuntural; una actuación ocurrida en algunos pocos años y motivada por el saqueo y el pillaje.
} 
el comercio de bienes extranjeros desde México hacia Perú por el Pacífico no generó ningún efecto positivo para la economía española. El Pacífico monárquico, titulado como un mare clausum, carecía de contenido.

Ahora bien, el funcionamiento y dinámica del comercio por el lago indiano fue una de las piezas clave para la constitución de un tejido comercial a escala imperial y global, que ubicó a la ciudad de México como su "corazón". Esta se convirtió en el principal punto de acopio y redistribución de mercaderías extranjeras por todo el espacio hispanoamericano. El tejido funcionó con suma intensidad en dos periodos concretos: 1580-1640 y 1680-1740 (Bonialian, 2014, pp. 27-82). Dos de los tres circuitos que conformaron las "columnas" del tejido se desarrollaron por el lago indiano: el eje transpacífico del Galeón de Manila y los contactos ilícitos entre México y Perú por el Mar del Sur. El tercer circuito se ubicó por el lado Atlántico, motorizado por la flota de Veracruz. La flota española, medio de unión entre el puerto de Cádiz con el de Veracruz, y el eje transpacífico, que enlazaba a las islas Filipinas con el puerto de Acapulco a través del Galeón de Manila, permitió que la ciudad de México se transformase en el principal depósito y reexpedición de mercaderías extranjeras por Hispanoamérica (véase diagrama 1).

Brindamos pruebas del notable fraude practicado por ambos conductos, superando los topes legales impuestos por la corona española para la exportación de metálico (hacia China y Europa) y la importación de bienes asiáticos y europeos a Nueva España. Los ingresos de géneros europeos a la ciudad de México - un acto a conciencia de los grandes comerciantes del Consulado- no sólo respondieron a la demanda del mercado interno del virreinato (único espacio permitido para el consumo de bienes asiáticos), sino que, de forma paralela, crearon un sobrante disponible para su nueva exportación a los mercados externos del virreinato, como Perú, Nueva Granada, Cuba y Centroamérica.

El más trascendente circuito de abastecimiento que logró desprender Nueva España fue con el virreinato de Perú a través del lago indiano. Navíos peruanos se movilizaron hacia la costa novohispana del Pacífico para adquirir los productos europeos y asiáticos a precios más bajos que los ofrecidos por la vía oficial de los galeones y ferias en Portobelo. En el intercambio, los peruanos ofrecían a los comerciantes novohispanos plata, azogue, cacao, aceite y vinos (Monségur, 1994, p. 219). La reexpedición de los efectos extranjeros fue también una realidad desde Veracruz hacia Cartagena y Portobelo. Pero el gran desarrollo del contrabando europeo por el área del Caribe, más la presencia de los galeones de Tierra Firme, contribuyeron a que la ruta de bienes ultramarinos que salían desde Veracruz hacia Cartagena fuera relativamente delgada, sin alcanzar la intensi- 


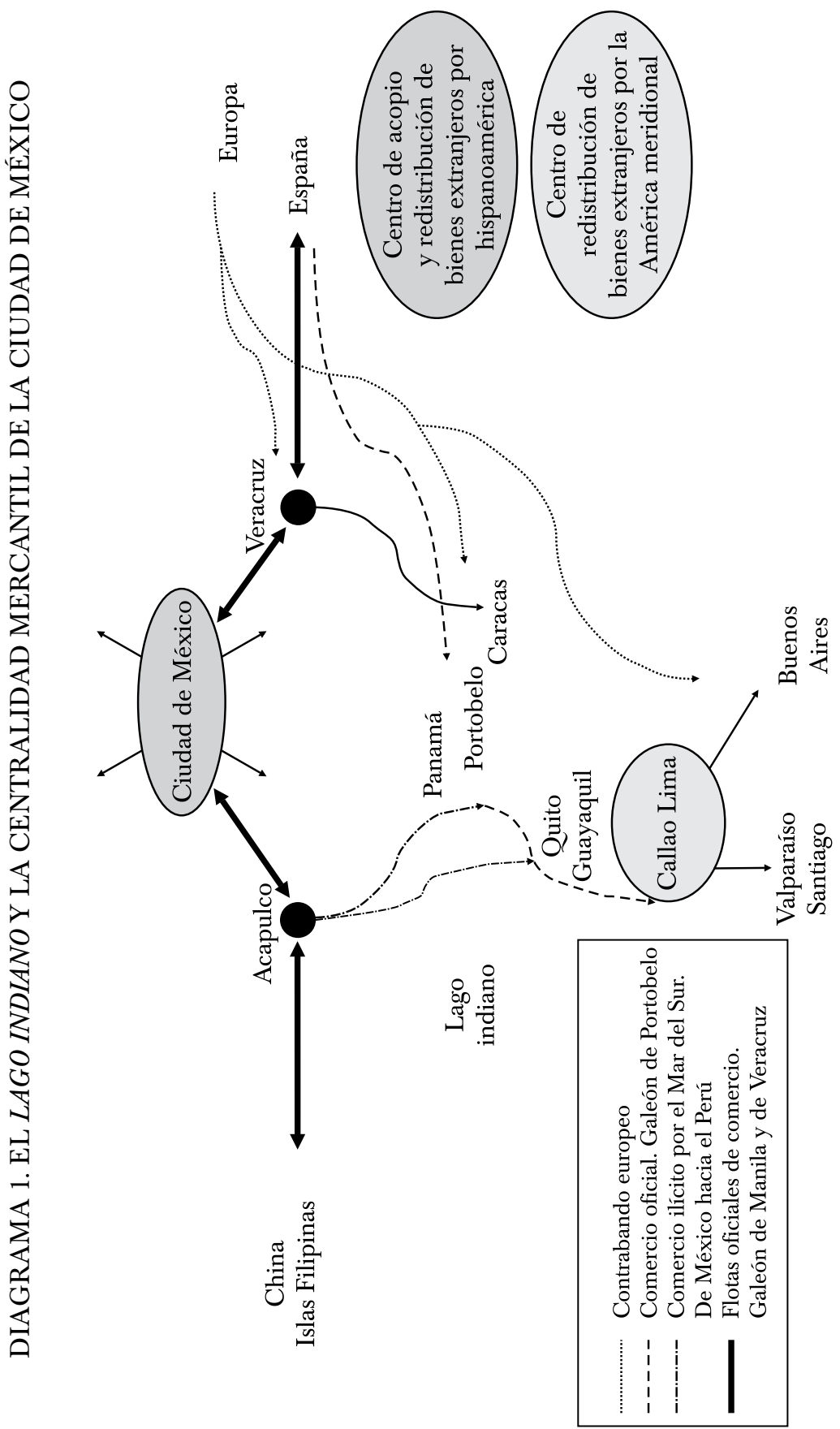

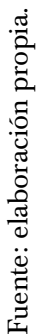


dad que sí adquirió la vía del lago indiano (Moutoukias, 1988; Suárez, 2001; Vila-Vilar, 1982).

Presenciamos un esquema de intercambio de larga duración por el lago indiano con la capacidad para intervenir y condicionar el régimen español trasatlántico. La protección política para el libre desenvolvimiento de los agentes mercantiles permitió que el comercio fraudulento por el Pacífico se desarrollara con autonomía, repercutiendo en los grandes flujos existentes por el otro gran océano. El movimiento de bienes y plata entre México y Perú provocó un doble efecto sobre la Carrera de Indias: a) otorgó impulso al comercio de flotas por Veracruz, ya que una porción de los bienes europeos ingresados por el Sotavento se internó hacia la ciudad de México y tomó rumbo hacia el mercado de Perú a través del Mar del Sur; b) contribuyó a recurrentes crisis en los galeones de Portobelo (1580-1630), hasta su desaparición en 1740 (Vila-Vilar, 1982). Todos los agentes económicos del imperio participaron con plena conciencia para que el modelo que ubicaba como centro a la ciudad de México funcionara. Incluso, los cargadores españoles fueron funcionales al mostrar desinterés en las ferias sudamericanas y priorizar los intercambios con el virreinato novohispano.

El tramo final del lago indiano terminó por "confundirse" con el circuito oficial que unía a Panamá con El Callao, a través de la Armada del Sur (véase diagrama 1). Los bienes europeos y asiáticos llegados a las plazas del occidente sudamericano desde Nueva España se definieron en calidad de bienes legales del galeón de Portobelo. Ya sea por Nueva España o por Panamá, la ciudad de Lima logró convertirse en el principal centro de acopio y de redistribución de bienes asiáticos y europeos por la Sudamérica hispana. El segundo punto de redistribución fue Quito, con la puerta de acceso de Guayaquil. De hecho, cabía la posibilidad de que los bienes que llegaban a la ciudad ecuatoriana fueran nuevamente reexpedidos a Lima (Ulloa, 1953, pp. 205-206). De Lima, las mercaderías extranjeras se traficaban vía terrestre hacia la parte más austral del continente, alcanzando el centro de Santiago de Chile o, vía Tucumán-Córdoba, al puerto atlántico de Buenos Aires.

En suma, todos estos elementos permitieron caracterizar al lago indiano como un área con gran dosis de autonomía, plenamente americana. Insistimos, hasta la primera mitad del siglo XVIII, el Pacífico hispanoamericano contó con una fuerte identidad indiana porque los actores que dinamizaron su economía mercantil fueron propiamente agentes que residían y concentraban sus intereses en Nueva España y en Lima (al margen de su origen o descendencia propiamente peninsular). Ellos lograron condicionar los flujos trasatlánticos del monopolio español. Previo a las reformas borbónicas de la segunda parte del siglo XVIII, el Atlántico fue un espacio pacificado. A partir de la segunda parte de la centuria, la modalidad de relación entre 
ambos océanos se invirtió, donde el Pacífico sufrirá su atlantización, su europeización. De este gran fenómeno se ocupará el presente trabajo.

\section{CRISIS Y DiSOluCIÓN DEL GALEÓN DE MANILA: CORAZÓN DEL LAGO INDIANO}

El lago indiano comenzó su decadencia y desmoronamiento hacia la segunda mitad del siglo XVIII. ¿Las razones?: concentrar la atención en la evolución comercial del Galeón de Manila, la pieza clave de aquel lago indiano, podría ofrecernos, en principio, algunas respuestas. Sin embargo, es necesario extender el mapa de análisis. No alcanzará con reconocer los obstáculos que comenzó a sufrir la relación entre las islas Filipinas y Acapulco para comprender íntegramente el desmoronamiento del complejo económico del lago indiano.

En líneas generales, la historiografía tradicional consideró las luchas de la independencia y la invasión napoleónica a España como los hitos fundamentales de la desaparición del Galeón de Manila (Díaz-Trechuelo, 1965, pp. 14-16; Valdés, 1987). Sólo desde una perspectiva de Estado-nación y aunado a la coincidencia temporal de los acontecimientos, la explicación, en definitiva, se justificaría. Asimismo, la historiografía más especializada que se concentró sobre el periodo colonial propone dos acontecimientos coyunturales para explicar el momento del descenso de los volúmenes comerciales del Galeón de Manila. Por un lado, se dice que la crisis comenzó en 1743 con la captura de los tesoros en plata de la nao Covadonga por el pirata inglés Anson. Veinte años después, en 1762, se desencadenó la invasión a Manila por parte de Inglaterra, que vino a agudizar la decadencia del eje transpacífico. El control inglés de manera circunstancial generó, según esta interpretación, un creciente desinterés en la inversión de capitales mercantiles en el galeón durante toda la segunda mitad del siglo XVIII (Álvarez, 2007, pp. 206-207; Yuste, 2007, pp. 149-150). Vale reconocer que algunas de las preguntas que aquí presentamos para comprender el fin del Galeón de Manila ya fueron planteadas, bajo principios de la teoría neoclásica, por historiadores. El trabajo de Mejía (2011) propone que el fin del Galeón de Manila obedeció a la notable reducción de la tasa de ganancia, dada la presencia del comercio de mercaderías británicas. En otro trabajo simultáneo que se complementa con el presente, abordamos preguntas similares a las de Mejía. ${ }^{2}$ Pero estamos lejos de comprender el problema

${ }^{2}$ Nuestro segundo ensayo, titulado "México: de epicentro a periferia. La desintegración del modelo semiinformal del comercio hispanoamericano (1750-1840)", se estaría publicando de manera paralela en la revista Historia Mexicana de El Colegio de México. Allí analizamos los factores 
bajo una interpretación neoclásica. Proponemos una explicación estructural y geoespacial de la crisis, de larga duración, integrando hechos históricos sucedidos en el Atlántico como en el Pacífico sudamericano que, a priori, no parecen tener responsabilidad.

Ahora bien, identificamos tres factores clave que provocan la crisis del lago indiano y del Galeón de Manila. Dos de ellos suscitados en el marco de las llamadas reformas borbónicas y del paquete de medidas de libre comercio de los borbones. Uno de ellos fue la competencia que comenzaron a gestarle al galeón filipino la aparición de los barcos de las compañías comerciales peninsulares por el Pacífico novohispano. Surgidas al calor de las aperturas portuarias y de rutas, las instituciones comerciales peninsulares iniciaron un tráfico entre China, el Pacífico mexicano y sudamericano al tiempo cuestionaron el monopolio que hasta entonces gozaba la Nao de China. La segunda razón consistió en el cierre del mercado de Perú al comercio de bienes extranjeros procedentes de Acapulco. La inauguración de la vía por el Cabo de Hornos (1740) para el tráfico de navíos de registro procedentes de Europa (primero navíos españoles y luego ingleses y angloamericanos) rompió con una de las "arterias" principales del lago indiano: el flujo de contrabando de bienes extranjeros desde México hacia los puertos de Panamá, Ecuador, Perú y Chile. Consideramos que el eje por el Cabo de Hornos resultó ser la primera ola de "atlantización" del Pacífico por su frente sur. El tercer factor, que sería la segunda ola de atlantización del lago indiano y que le aplicó el golpe mortal al Galeón de Manila estaría en el comercio practicado por agentes locales e ingleses de mercaderías británicas y asiáticas, realizado desde Jamaica vía Panamá hacia el puerto mexicano de San Blas durante las primeras décadas del siglo XIX. Pasemos a analizar estos tres fenómenos.

\section{COMPAÑÍAS COMERCIALES PENINSULARES Y EL FIN DEL MONOPOLIO DE ACAPUlCo EN EL TRATO ASIÁTICO}

A partir de 1760 nuevos agentes y corporaciones españolas vinieron a cuestionar el papel dominante de los comerciantes novohispanos en el trato transpacífico. En un contexto de medidas de libre comercio, compañías de origen peninsular comenzaron a importar bienes asiáticos a los puer-

\footnotetext{
que contribuyeron a la pérdida de la centralidad de la ciudad de México en el comercio global e imperial, las razones del nacimiento de nuevos consulados en Hispanoamérica durante el último cuarto del siglo, el descenso en la producción textil local novohispana ante la revolución comercial y productiva de Gran Bretaña, así como también las consecuencias que tuvo para el comercio asiático la "invasión" del textil inglés en los mercados americanos. La lectura del ensayo "México: de epicentro a periferia" contribuiría a reforzar las hipótesis que aquí aparecen.
} 
tos occidentales hispanoamericanos con el propósito de adquirir grandes cantidades de monedas de plata que se estaban produciendo, como en sus mejores épocas, en Perú y en Nueva España (Cross, 1983, p. 403). Las entidades peninsulares compitieron exitosamente con los intereses novohispanos depositados en el comercio del galeón, provocando la disminución de los volúmenes de importación de bienes y exportación de metálico que realizaba hasta entonces y de manera monopólica el tradicional galeón. ¿̇A qué compañías nos estamos refiriendo? Sobresalen los navíos de guerra y de comercio como el Buen Consejo y Venus, que ingresaron a la escena del Pacífico a partir de 1765 (Díaz-Trechuelo, 1965, pp. 17-18; Yuste, 2000, pp. 34-35). Dos años antes, en 1763, nacía la compañía de los Cinco Gremios Mayores de Madrid $^{3}$ y en 1779 la corporación de Uztáriz, San Ginés y Compañía con su navío Hércules, que circuló entre Perú, México y Filipinas (Ruiz, 1976, pp. 183-197; 1985, pp. 145-179). Sin embargo, la Real Compañía de Filipinas, que funcionó desde 1785 hasta 1834 promoviendo un comercio verdaderamente global entre Asia, América y Europa, fue la empresa comercial más reconocida y emblemática de la época (DíazTrechuelo, 1965; Villalobos, 1962, pp. 517-520).

Desde su fundación en 1768, el puerto novohispano de San Blas participó en el comercio con las islas Filipinas al romper con la tradicional exclusividad de Acapulco. Conforme avanzaba la segunda mitad del siglo, San Blas se fue convirtiendo en el puerto seleccionado para el arribo de los barcos de las compañías españolas en su trato con Asia o de la propia Nao de China. El protagonismo de los comerciantes españoles fue desplazando a los novohispanos en el control exclusivo del comercio transpacífico, llevando a la famosa feria de Acapulco a frecuentes situaciones de decadencia. La apertura portuaria y sus conexiones directas al trato asiático permitieron que los mercados y los comerciantes regionales y locales del interior del virreinato relajaran su subordinación con la ciudad de México. El caso más representativo de la pérdida de fuerza del eje Acapulco-ciudad de México, fue la constitución de la red espacial y de agentes que se configuró en torno a San Blas, Tepic y la ciudad de Guadalajara para la movilización de los productos asiáticos. La fundación del Consulado de Guadalajara en 1795 fue resultado del crecimiento mercantil de dicha red por la región del septentrión novohispano (Ibarra, 2000; Meyer, 2008).

La función de la ciudad de México como depósito de los bienes asiáticos ya no operará en su plenitud. El poder de irradiación del puerto de Acapulco como exclusivo punto redistributivo de bienes asiáticos hacia

\footnotetext{
${ }^{3}$ Contratación, vol. 5523, núm. 2, exp. 11. Archivo General de Indias, Sevilla (en adelante AGI). Véase también México, Duplicados de cartas de virreyes, Bucareli al rey, 1775, vol. 1372, s. f. AGI.
} 
el interior del virreinato novohispano y hacia el mercado peruano perdía significancia. Una de las funciones vitales del lago indiano se encontraba en franca decadencia. A partir de este momento, ni el Galeón de Manila, ni el puerto de Acapulco, ni los mercaderes de la ciudad de México serán los elementos exclusivos del trato transpacífico. Los bienes del oriente no sólo ingresarán al mercado novohispano por diferentes puertos del Pacífico virreinal, sino que también llegarán desde el Atlántico con la flota de Veracruz (en actividad hasta 1778 y desaparecida jurídicamente en 1789), con los navíos de registro y con el contrabando de los ingleses desde Jamaica.

Lo cierto es que Acapulco sufrió un estado de inestabilidad económica prolongado, generado por situaciones contrapuestas: suspensión de ferias, galeones semivacíos o, en casos excepcionales, sobrecargados que no respondían a las demandas precisas de un mercado que operaba, además, a un ritmo acelerado por la política de "libre comercio". La decadencia, la falta de fondos, la subsistencia, el estado deplorable, la quiebra y los precios abatidos fueron algunas de las tantas definiciones que brindaron los informes de los gobernadores de las islas Filipinas en relación con el estado del galeón filipino. ${ }^{4}$ En 1767, el contador general de Indias, Tomás Ortiz de Landazuri, advertía que la nao de Filipinas no sólo ya se veía en la imposibilidad de responder la demanda peruana de géneros del Asia, sino que tampoco ofrecía "las necesarias para México" (Navarro, 1965, p. 41).

Aquellas apreciaciones también fueron ilustrativas de las mínimas cargas que transportaba el Galeón de Manila hacia Nueva España. Si el permiso de importación alcanzaba las 4000 piezas, desde 1760 sólo se vieron ingresar un número de piezas que iban desde $350 \mathrm{y}$, en condiciones excepcionales, 2000 (Yuste, 2000, pp. 383-387). Recordemos que, en pleno auge del comercio por el lago indiano, los ingresos de mercancía oriental a través del Galeón de Manila superaban el tope de 4000 piezas en cada viaje (Abreu, 1977) o, como el caso del galeón El Rosario que llegó a transportar en un año de la década de 1740 hasta 18667 piezas (Cruz, 1962, p. 117). A partir de 1750, el escenario fue totalmente opuesto, si las condiciones eran favorables, los comerciantes que habían depositado sus capitales en el galeón debían contentarse con disponer y vender tan sólo la mitad de piezas de lo autorizado por la legislación borbónica. ${ }^{5}$

\footnotetext{
${ }^{4}$ Filipinas. Informe del marqués de Ovando de 1754, 335, leg. 16, f. 436. AGI, Sevilla; Filipinas. Informes de Manuel de Arandía, Instituciones Coloniales, vol. 3, exp. 18, f. 316v. Archivo General de la Nación (en adelante AGN), México; Indiferente virreinal. Cartas al virrey referentes al tráfico comercial de las islas Filipinas, 1755, Instituciones Coloniales, vol. 3693, exp. 18, f. 18. AGN.

${ }^{5}$ Filipinas. Informe del comercio de Manila al Consejo de Indias sobre alteraciones de comercio, 1753, 268, s. exp. AGI. Véase también el informe del fiscal Leandro de Viana de 1767 en Filipinas. Informe de los abusos de este comercio, 1767, vol. 941, s. exp. AGI.
} 
Así como el número de mercaderías asiáticas traídas por el galeón a Acapulco descendía, también disminuían las monedas de plata peruana y novohispana que desde el puerto guerrerense se despachaban hacia el oriente. Desde 1750 hasta su desaparición en 1815, el Galeón de Manila sólo logró, en excepcionales y contados años, cargar en sus bodegas 1500000 pesos en cada viaje hacia el Oriente (Yuste, 1984, p. 130), cuando sabemos que en las primeras décadas del siglo XVIII las cantidades exportadas eran entre 3000000 y 4000000 de pesos anuales (Abreu, 1977; Hang-Shen, 1997, pp. 845-853). Es muy importante que no confundamos el descenso de las exportaciones de plata hacia China a través del tradicional galeón, con las salidas generales de metálico que comenzaron a realizarse hacia diferentes destinos desde los puertos del Pacífico mexicano. Si sumamos la multiplicidad de vías de drenaje que aparecieron desde la segunda mitad del siglo XVIII y durante las primeras décadas del siglo XIX, llegaríamos a la conclusión que el volumen de plata mexicana superó con creces los niveles registrados de épocas anteriores. Más si tomamos en cuenta que la producción de plata por Nueva España se encontraba en franco ascenso. La razón fundamental del descenso en las exportaciones directas de plata hacia China estaría en la aparición de nuevos mercados externos atraídos por la moneda mexicana y en la multiplicidad de nuevas rutas y compañías comerciales marítimas que canalizaban el metal mexicano rumbo a China, Estados Unidos, Canadá o hacia la propia Europa (McMaster, 1959, pp. 372-380). ${ }^{6}$ Lo que resulta fundamental en nuestro argumento es que el Galeón de Manila, como el engranaje clave que motorizaba el tejido mercantil por el lago indiano, entraba en una fase de irreversible agonía. Pero ya es momento de ampliar nuestro horizonte geográfico y notar que el deterioro del tráfico por el tradicional eje transpacífico respondió a fenómenos mercantiles que superaban la geografía específica del Pacífico mexicano.

\section{LA PRIMERA OLA DE ATLANTIZACIÓN DEL PACÍFICO: EL EJE POR EL CABO DE HORNOS}

Desde la segunda mitad del siglo XVIII, el paso por el Cabo de Hornos para comunicar a España directamente con China tomó un inusitado interés para la corona borbónica (Alfonso y Martínez, 2013, pp. 307-340). La ver-

\footnotetext{
${ }^{6} \mathrm{~A}$ inicios de la independencia de Estados Unidos (1779), las letras de cambio que se pagaban al Congreso nacional debían ser en pesos mexicanos y seis años más tarde, hacia 1785, el propio Congreso declaró al peso en plata mexicano como la unidad monetaria nacional para los intercambios hasta 1857.
} 
dad es que, salvo contados viajes que lograron emprender los barcos de la Real Compañía de Filipinas, la comunicación directa resultó más bien un sueño que una realidad concreta. La vía española por el Cabo de Hornos tuvo, sin duda, mayor impacto para el caso sudamericano que para el mercado asiático. En líneas anteriores, advertimos que otra de las causas que sumergieron en un estado crítico al Galeón de Manila fue el de haber perdido su función como fuente de abastecimiento de bienes extranjeros al mercado de Perú, una de las rutas principales del lago indiano. Es que el frente de suministro cambió rotundamente de sentido a partir de 1750 . La desaparición de los galeones, con sus respectivas ferias de Portobelo, posicionó al navío de registro español como el medio de transporte dominante para proveer de mercancías extranjeras a los mercados del Pacífico sudamericano. A partir de entonces, los barcos de registro contarán con la autorización oficial para cruzar el Cabo de Hornos y vender en los puertos efectos europeos y asiáticos en las costas de Chile, Perú y Ecuador. Estamos en presencia de lo que llamamos la primera ola de "atlantización" del Pacífico (véase diagrama 2). ${ }^{7}$ El trayecto realizado por navíos europeos desde Europa hacia el Pacífico sudamericano por el Cabo de Hornos golpeó desde sus estructuras el tejido que posicionaba al lago indiano y a la ciudad de México como principales espacios distribuidores de bienes extranjeros por Hispanoamérica.

La nueva ruta por el eje austral le arrebató al Galeón de Manila y a los mercaderes de la ciudad de México la posibilidad de reexpedir hacia el mercado sudamericano grandes porciones de mercadería asiática, negocio de gran rentabilidad para los tiempos del lago indiano. En efecto, cuando la ciudad de México se convertía en el gran depósito de bienes extranjeros, la ciudad principal del espacio peruano, Lima, llegó a ser calificada por un funcionario de la época como la "feria de Pekín", a raíz de la gran distribución y consumo de tejidos y sedas orientales que deslizaban, como una suerte de cascada, desde Acapulco (Bonialian, 2012, p. 347). La definición no podría representar el escenario que desde 1750 vivió Lima. Una sencilla razón lo confirma: prácticamente desaparecieron las reexportaciones ilícitas de bienes orientales y europeos desde el Pacífico novohispano hacia Perú. Hemos registrado en su momento que entre los años 1670 y 1740 se dirigieron más de 80 embarcaciones limeñas con plata, azogue, cacao y vino a los puertos del Pacífico mexicano. Veinticinco de ellos -cifra oficial y por cierto mínima, que no refleja el contraflujo- habían retornado con mercadería local, asiática, europea y de Castilla a los puertos del Ca-

\footnotetext{
${ }^{7}$ La segunda ola de "atlantización" del Pacífico se dio con el contrabando inglés JamaicaPanamá-San Blas durante las primeras décadas del siglo XIX; problemática de la que nos ocuparemos en el último apartado.
} 


\section{DIAGRAMA 2. EL FIN DEL LAGO INDIANO Y LA ATLANTIZACIÓN DEL PACÍFICO}

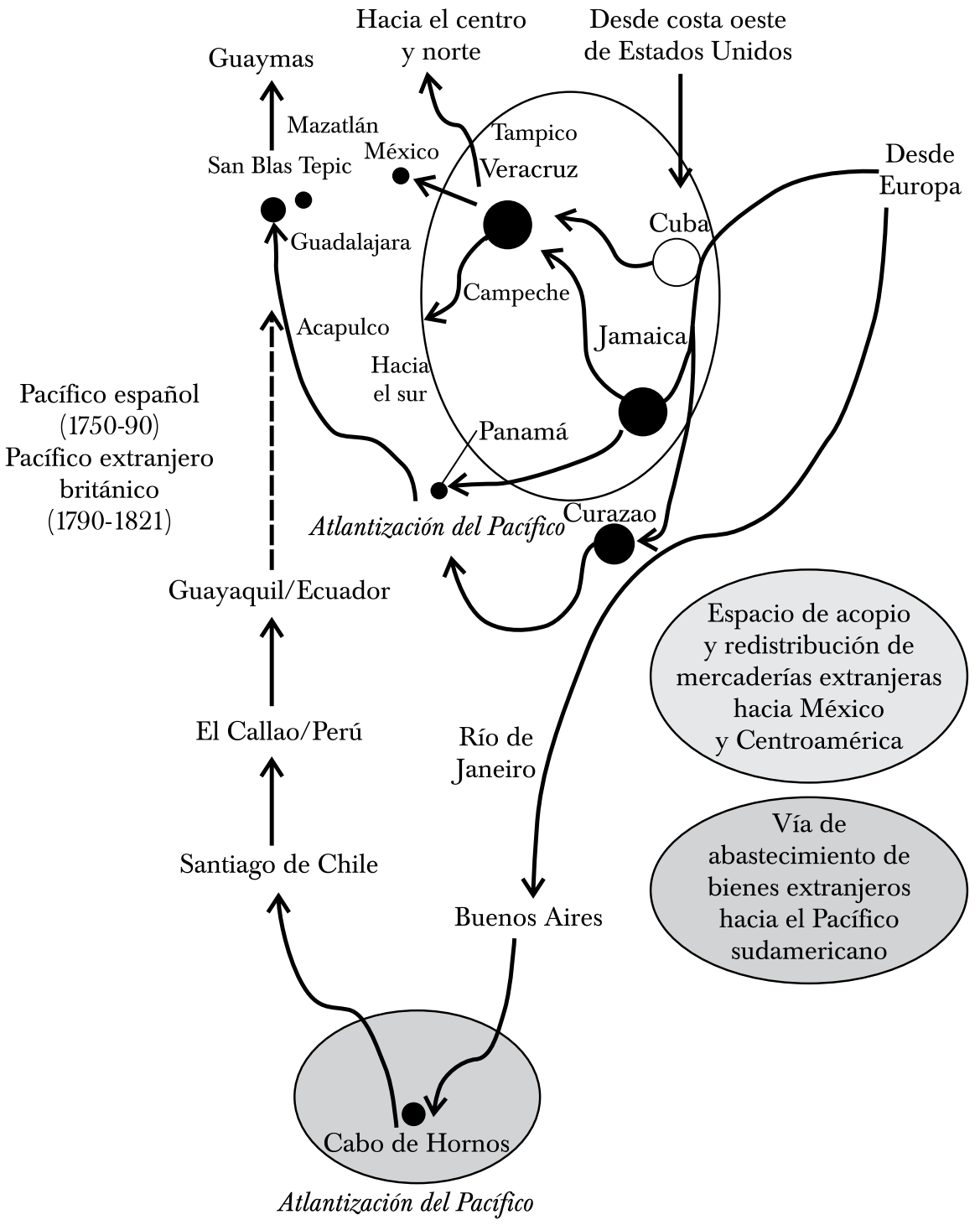

Fuente: elaboración propia. 
llao, Guayaquil o Paita (Bonialian, 2012, pp. 302-303). Lo sorprendente es que, apenas iniciada la segunda mitad del siglo XVIII, esta composición de bienes desde México hacia Perú por el Pacífico no continuó en lo más mínimo. La medida de libre comercio para el tráfico de embarcaciones particulares por el puerto de Buenos Aires o hacia el Valparaíso, Lima y Guayaquil vía Cabo de Hornos daba cuenta del avance español sobre un espacio marítimo sudamericano que en el periodo anterior funcionaba con otras lógicas de comercio, más vinculadas a México y a la economía asiática (Flynn y Giráldez, 2014, pp. 29-76).

Es sabido del auge comercial que gozó el cacao guayaquileño hacia México durante la segunda mitad del siglo XVIII (Contreras, 1990; Borja y Nagy, 1964, pp. 1-50; Miño, 2013; Valle, 2010, pp. 181-206). La política comercial borbónica aplicada en 1774 para la libertad en la circulación de ciertos bienes de producción local entre ambos virreinatos impulsó su comercialización. ${ }^{8}$ A pesar del auge del tráfico del grano de sur a norte, no vemos aparecer en los documentos retornos de bienes extranjeros desde México hacia Perú que habían sido frecuentes cuando funcionó el lago indiano. A partir de 1750 las mercaderías asiáticas y europeas que se consumieron desde Panamá hasta las regiones más australes del continente ya no procedían de México, sino de Europa, vía el Atlántico, a través de la ruta por el Cabo de Hornos realizada por los navíos de registro o por las mencionadas compañías peninsulares que operaban directamente desde Cantón.

En el año 1748, apenas inaugurada la ruta austral, recalaron en el puerto peruano de El Callao unos 18 navíos de registro españoles. Para 1761, la cifra aumentó a 56. En 1786, sólo al puerto limeño llegaron 16 navíos de registro desde el estrecho austral. Para los años finales del siglo XVIII, el promedio de embarcaciones anuales que llegaron al puerto del Río de La Plata fue de 60, muchas de las cuales extendieron su travesía hacia el Pacífico por el Cabo de Hornos (Villalobos, 1965, pp. 40-56). Entre 1778 y 1796 circularon de Cádiz a El Callao unos 153 barcos, y entre 1809 y 1820 unos 90 (Parrón, 1995, p. 320). Estas embarcaciones importaron telas crudas o terminadas, hierro, acero, artículos de ferretería, cera, papel, libros, medicamentos, vidrio y especies del oriente por los puertos de Chile, Perú y Ecuador. Una mención especial requiere el rubro de los textiles o, como se la llamaba en su momento ropa. Durante la segunda mitad del siglo XVIII los textiles de origen europeo y, en menor medida, de China e India, representaron $65 \%$ de la canasta importadora por Lima. A cambio, los

\footnotetext{
${ }^{8}$ Reales cédulas. Instituciones coloniales, Reales cédulas, vol. 104, exp. 10, fs. 1-5; Indiferente virreinal. Instituciones coloniales, caja 2790, exp. 10, fs. 1-8. AGN.
} 
navíos españoles exportaron a Cádiz grandes cantidades de plata de Perú (Lamikiz, 2010, pp. 83-84).

¿Por qué la ruta del Cabo de Hornos tomó tanta relevancia como para minimizar el tráfico oficial por Panamá? ${ }^{9}$ El reglamento de libre comercio sólo autorizó y privilegió el tráfico directo por el estrecho austral con los puertos de Buenos Aires y, para el caso del Pacífico, con Valparaíso, Concepción de Chile, Arica, El Callao y Guayaquil. Para el caso de Panamá sólo se permitió envíos de efectos sólo para su consumo interno. En la situación excepcional que se solicitara su reexpedición hacia los puertos del Mar del Sur debían pagar nuevamente impuestos, por lo que el costo de comercialización se encarecía en relación con los enviados por la ruta del cabo austral. Las mercaderías españolas que llegaban a Panamá vía España pagaban 1.5\% menos de los impuestos que pesaban a los de la ruta del Cabo de Hornos, mientras que a los bienes extranjeros les pesaba un impuesto de 3\% menos, respectivamente. Si se reexportaban desde Panamá las mercaderías no sólo debían saldar estas diferencias, sino afrontar un nuevo impuesto por los puertos del Pacífico, 3\% para los bienes españoles y $7 \%$ para los extranjeros. ${ }^{10}$ Hasta la primera mitad del siglo XVIII, Valparaíso, Paita y Guayaquil dependieron de los dictados por los ejes México-Acapulco-Callao o por el impulso que podía darles el eje atlántico de Portobelo-Callao. Con la apertura del Cabo de Hornos, estos espacios lograron disminuir su tradicional dependencia respecto de Lima y dinamizar la relación directa con España y con el puerto de Buenos Aires. Un caso muy representativo fue el eje Valparaíso-Santiago de Chile. Tanta importancia habría alcanzado el polo chileno que, según especialistas, se convirtió en el puerto dominante del Pacífico sur en el transcurso de la segunda mitad de aquella centuria (Carmagnani, 2000).

Por lo anterior, cabe cuestionar si estos navíos de registro que surcaron el Cabo de Hornos hacia los mercados del Pacífico alcanzaban las costas occidentales de México. Aquí ingresamos a un fenómeno complejo. Apoyados en la revisión de documentación, podemos señalar que hasta 1790 la extensión de los navíos particulares españoles hacia el Pacífico norte resultó excepcional, más considerando que entre 1760 y 1790 se exploraron desde la costa mexicana nuevas líneas de comercio de cabotaje y de expedición hacia el norte, rumbo a California. La sistematicidad de

\footnotetext{
${ }^{9}$ Repetimos comercio oficial porque no podemos desconocer la presencia del contrabando inglés que cobró notable importancia por el Caribe centroamericano y por las regiones del norte de Sudamérica como Cartagena y Nueva Granada.

${ }^{10}$ Gobierno virreinal. Arancel de los derechos señalados por Carlos III, rey de España, para las embarcaciones del comercio libre y las que hacen el comercio interior de unos puertos a otros por los mares del norte y sur de América. España, expedido el 16 de febrero de 1778, e Instituciones coloniales, Impresos oficiales, vol. 11, exp. 3, fs. 15-23. AGN.
} 
los intercambios realizados por los navíos de registro habría llegado hasta la zona de Ecuador, ocasionalmente a México. Pero la clave en nuestro argumento es reconocer que la inauguración de barcos peninsulares por la ruta de Cabo de Hornos le arrebató al eje ciudad de México-Acapulco esa función de eje abastecedor de bienes extranjeros sobre el mercado de Perú, al romper aquella centralidad que supo gozar la ciudad de México como punto redistribuidor de mercancías extranjeras.

Ahora bien, el desmoronamiento de ese lago indiano se profundizó a partir de la última década del siglo XVIII, con la entrada de balleneros británicos y angloamericanos por el Cabo de Hornos. Gracias al tratado de paz anglo-español de San Lorenzo (1790), más el decreto del comercio de neutrales en 1797, la corona hispánica prácticamente cedió la ruta del Cabo de Hornos a balleneros y buques de guerra británicos. Ramiro Flores (2010) afirma que el tratado de 1790 representó la "desnacionalización del comercio peruano", en el sentido que al amparo de la autorización que benefició a los ingleses arribaron también naves estadunidenses y de otras naciones al Pacífico español (Flores, 2010, pp. 63-64). ${ }^{11}$ Con ellos, el Pacífico mexicano quedaba entrampado en una amplia red mercantil comprendida desde Chile hasta China, pasando por California. Los buques ingleses concebían a la plata de Perú y de México como la principal mercancía a adquirir. Para ello, tejieron un enorme comercio que combinó trayectos de larga distancia y comercio de cabotaje.

Los balleneros cruzaban el Cabo de Hornos y despacharon bienes europeos (pero también si bien en menor dimensión efectos asiáticos) en los puertos de Chile, de Perú, de Panamá o los del Pacífico mexicano. Adquirían en ellos productos locales como trigo chileno, vinos y aceite de Perú y cacao de Guayaquil. Prolongaron su comercio en Asia para adquirir algodones y especias de India, sedas y porcelanas de China. A su retorno, estos últimos productos fueron intercambiados por pieles de nutria y focas, ya sea para venderlos en las costas norteñas de México y de Estados Unidos o destinarlos al mercado europeo donde gozaban de estima y elevados precios. En 1794 habrían llegado al puerto de Acapulco entre 25000 y 30000 cargas de cacao procedentes de Guayaquil por un valor estimado en 300000 pesos. El virrey novohispano, Revillagigedo, afirmó que este comercio se paga "en dinero casi enteramente" (Hamerly, 1973, p. 125). La pregunta es sobre el destino de la plata mexicana que llega a Ecuador a través de este intercambio. Es muy posible que estas cantidades de monedas fueran absorbidas por los comerciantes balleneros británicos,

\footnotetext{
${ }^{11}$ La interpretación es compatible con nuestra idea de un Pacífico extranjero que proponemos en las conclusiones.
} 
como una pieza más del entramado comercial que realizaban por todo el Pacífico hispanoamericano.

El estudio de Trejo (2006a, pp. 24-25) alista 30 buques de compañías balleneras británicas que operaron entre 1793 y 1820 por el Pacífico mexicano, luego de haber cruzado el estrecho austral y visitar Valparaíso, El Callao y Guayaquil. Otros estudios (Pereira, 1971, pp. 315-353) constatan que, desde 1788 hasta 1809 navegaron 165 buques ingleses y estadunidenses entre los puertos y mercados del espacio comprendido entre Valparaíso hasta California. Villalobos (1965, p. 94) nos ofrece una cifra más elevada para el mismo periodo de 257 barcos. Jorge León (2001, p. 326) contabilizó unos 80 barcos balleneros y cazadores de pieles por los puertos de Chile, Perú y México hacia 1800, participando en un activo contrabando que respondió a la gran demanda de bienes europeos de los mercados del Pacífico hispanoamericano. Entre 1817 y 1818 había en las costas peruanas más de 100 balleneros estadunidenses que habrían alcanzado el occidente mexicano (Flores, 2010, p. 85).

De tal manera, los navíos europeos, mayormente británicos, se apropiaron hacia la última década del siglo XVIII de la ruta austral, derrotero que décadas anteriores estuvo en manos de los mercaderes españoles con sus navíos de registro. Existía un lago indiano antes de 1750. Luego, durante las cuatro décadas comprendidas entre 1750 y 1790 se conformó un lago español con la aparición de las compañías peninsulares y la inauguración para la navegación de los navíos de registro españoles de la ruta del Cabo de Hornos. Desde 1790 y durante todo el sigo decimonónico se constituyó un Pacífico extranjero en razón que la movilización de capitales, navíos y productos eran de origen particularmente británico. En suma, la presencia de barcos ingleses y estadunidenses que extendían su derrotero hacia China y Filipinas fue un problema para el comercio de un Galeón de Manila que primero sufrió con la competencia de las compañías peninsulares y posteriormente del comercio británico.

Lo que resulta importante para el Pacífico mexicano es que ya sea con los navíos de registro españoles o tiempo después con los balleneros británicos, se produjo un importante cambio en lo referido a la orientación de suministro de los bienes extranjeros. Si antes de 1750 la modalidad de abasto fluía desde México hacia Sudamérica, desde esa fecha notamos que por las costas occidentales novohispanas se importaban bienes europeos desde el sur del Pacífico. En este contexto la corona española autorizó, hacia 1794, el libre comercio de estos bienes extranjeros entre los puertos de Chile, El Callao, Guayaquil y el Pacífico mexicano. ${ }^{12}$ La medida facili-

\footnotetext{
${ }^{12}$ Bandos. Real orden que permite la extracción e introducción de frutos, mercaderías y efectos de Europa entre este reino y el del Perú por los puertos del Sur, abril de 1795, Institucio-
} 
tó para que los balleneros británicos y embarcaciones locales importaran manufactura extranjera por los puertos occidentales de México. En 1802, el paquebote Marte ingresaba efectos europeos y de Perú al puerto de Acapulco sin pagar derechos. ${ }^{13}$ Hacia 1818, según el gobernador de Nueva California, se presentó por sus costas la fragata Hermosa Mexicana, propiedad del comercio de Lima, al mando del capitán Gaspar Yllas con textiles de algodón inglés procedente de El Callao. ${ }^{14}$ Los casos relatados muestran que el Pacífico mexicano abandonaba aquella función de reexpedir bienes extranjeros por el Mar del Sur; una operación clave que hizo en su esplendor el comercio del lago indiano. Ahora, en tiempos que vemos conformarse un Pacífico extranjero, se realizaba el proceso inverso.

Con respecto a la circulación de mercaderías asiáticas, su libertad para conducirlas libremente desde Acapulco hacia Guatemala y el Perú se efectivizará recién en el año $1803 .^{15}$ No fue casual que la autorización llegara en pleno contexto de políticas de libre comercio. Para entonces, una multiplicidad de flujos y puertos desde el Atlántico y desde el Pacífico estaban movilizando e ingresando bienes y textiles asiáticos por Hispanoamérica (Bonialian, 2012, pp. 367-414) En este contexto, la libertad concedida al Galeón de Manila no representó un peligro para España, como sí lo había sido en las primeras décadas del siglo XVIII, cuando se llegó a prohibir el ingreso de sedas chinas por Acapulco por los problemas que suscitaba al comercio peninsular por el puerto de Veracruz. ${ }^{16}$ Durante la segunda mitad del siglo XVIII el panorama era bastante diferente. Los navíos particulares de Manila, los navíos de registro españoles o, más tarde, la propia Compañía Real de Filipinas habían logrado disminuir el exclusivismo comercial del Galeón de Manila para el trato asiático por México y por el Pacífico sudamericano.

Los pocos estudios dedicados al comercio exterior mexicano de las primeras décadas del siglo XIX adoptan una perspectiva en los Estados-nación que concentra la atención en el horizonte del comercio de cabotaje o en los movimientos expedicionarios hacia el norte californiano desde San Blas o desde puertos más al norte de México. En verdad, hemos ofrecido elementos para pensar que el Pacífico mexicano continuó siendo un área

nes coloniales, vol. 18, exp. 10, f. 44. AGN. Véase también Bandos, vol. 20, exp. 87, f. 191; Real Hacienda. Instituciones coloniales, vol. 130, exp. 9, 1800, f. 1. AGN.

${ }^{13}$ Reales cédulas originales. Instituciones coloniales, vol. 183, exp. 1, enero de 1802, f. 4. AGN.

${ }^{14}$ Indiferente virreinal. Instituciones coloniales, caja 3915, exp. 33, 1818, f. 3. AGN.

${ }^{15}$ Impresos oficiales. Real cédula expedida por Carlos IV el 18 de septiembre de 1803, disponiendo el "fomento de la navegación y el comercio entre los reinos de Perú, Nueva España, Granada y Guatemala y los puertos del mar del Sur”, Instituciones coloniales, Gobierno virreinal, contenedor 22, vol. 54, exp. 41, 18 de septiembre de 1803, fs. 212-215. AGN.

${ }^{16}$ Reales cédulas. Instituciones coloniales, vol. 39, exp. 16, f. 2. AGN. Para un detallado proceso de la legislación véase Filipinas. vol. 333, exp. 112, fs. 193-234. AGI. 
permeable y móvil, con fuertes influencias a los cambios que se vivieron no sólo en el espacio de circulación naval sudamericana sino también del Atlántico. Tanto el Pacífico septentrional como el meridional fueron, en definitiva, piezas de una economía global más unificada: si antes de 1750 existió un lago indiano vinculado al polo asiático, desde finales del siglo XVIII el espacio del Pacífico se verá apuntalado por agentes, barcos y capitales de las economías europeas y estadunidense.

\section{LA SEGUNDA OLA DE ATLANTIZACIÓN DEL PACÍFICO: el comercio entre Jamaica, Panamá y San Blas}

Decíamos que la apertura de Cabo de Hornos fue la primera ola de atlantización que sufrió el Pacífico, rompiendo las lógicas comerciales que existían previamente por aquel lago indiano. Existió una segunda ola, en este caso más tardía y por el frente norte y mexicano, que contribuyó a que la amplia área marítima del occidente hispanoamericano se "atlantizara". Nos referimos al contrabando británico que enlazó los nudos portuarios de Jamaica, Panamá y San Blas. Apenas iniciado el siglo XIX se registró una verdadera invasión de mercaderías británicas movilizadas, en especial del rubro de textiles, a través de pequeñas embarcaciones locales e inglesas que entraron por los puertos occidentales de México. Esta segunda corriente de atlantización, llegada desde el Caribe al Pacífico mexicano fue la que, sin dudas, le propinó el último golpe a un moribundo Galeón de Manila.

Durante la segunda mitad del siglo XVIII, Jamaica se consolidó como la principal plataforma del contrabando inglés no sólo hacia el Caribe mexicano vía Cuba, sino como fuente de suministros ilegales de bienes a los mercados de Portobelo-Panamá. En el primer apartado del ensayo, señalamos que durante el siglo XVII y primera mitad del XVIII la ciudad de México, a través de sus lazos con Acapulco y Veracruz, se constituyó en el principal acopio de mercancías extranjeras para su redistribución por Hispanoamérica. Esa función de pivote que alcanzó la capital novohispana contribuyó al funcionamiento del lago indiano. Hacia la segunda parte del siglo, notamos que la unidad de acopio se trasladó hacia la región marítima atlántica de México y el Caribe. El reemplazo del centro de redistribución salta a la vista si comparamos los diagramas 1 y 2. Para el comercio oficial, la función recaía, en teoría, sobre el eje Cuba-VeracruzTampico (Nakamura, 2007, pp. 53-59). Desde los primeros años del siglo y reforzada en 1807, Carlos IV autorizó el comercio de La Habana con los puertos del Golfo de México, por ser Cuba una suerte de depósito de mercancías traídas desde España (Cárdenas, 1968, vol. I, p. 235). Para el 
caso del contrabando, aparecían Jamaica y otras islas occidentales británicas menores. Claro está que la distinción es bastante difusa, pues entre esos tres "enclaves" de almacenamiento de bienes existía una infinidad de puntos y escalas de islas caribeñas que "confundían" el comercio oficial del prohibido. De hecho, Curazao, bajo el dominio holandés, no debería dejarse de lado.

Abundantes estudios han reconocido la enorme fuente de aprovisionamiento de textiles que fue el Caribe británico para México, Panamá, Portobelo y Caracas (Pearce, 2007; Romano, 1998, pp. 60-83). En menor medida, otros especialistas dedicaron ensayos o pocas líneas a la extensión comercial desde el centro mercantil caribeño sobre el Pacífico mexicano, en especial sobre el puerto de San Blas (Cabañas, 1944; ${ }^{17}$ Cárdenas, 1968, vol. I, pp. 235-240; Pardo, 1994, pp. 83-90; Trejo, 2006a; Valdés, 1987, pp. 241-260). La problemática resulta trascendental para nuestro argumento, pues el contrabando de textiles ingleses que se realizó desde Centroamérica, pasando por el istmo panameño, hacia los puertos occidentales de México contribuyó a dos fenómenos: $a$ ) la decadencia irreversible del comercio de bienes asiáticos a través del Galeón de Manila; $b$ ) el relajamiento de las navegaciones europeas procedentes de Cabo de Hornos hacia el Pacífico mexicano.

Hemos concentrado la atención sobre las razones estructurales que llevaron a la crisis del galeón asiático. Identificamos en el primer apartado que esa decadencia se inició durante las reformas borbónicas. Lo que ahora vemos es que esa crisis se agravó en el contexto de las luchas por la independencia de México. La toma de Acapulco y del Galeón de Manila por parte de los insurgentes al mando de Morelos en los últimos meses de 1810 hizo reflotar la idea en la mesa política de la monarquía sobre el definitivo cierre del tradicional eje transpacífico (Valdés, 1987, pp. 213-231). Acapulco, en un estado económico y social decadente, ya había sido desplazado por San Blas como puerto principal para las navegaciones directas con el Oriente. El comercio de Manila advirtió sobre el peligro de verse abandonado el lazo económico con México y demostró su plena voluntad para reactivar la conexión. Es así que, en ese mismo año, el consulado filipino no dudó en proponerle al comercio de Guadalajara el envío de tres expediciones comerciales directas al puerto de San Blas. ${ }^{18}$ La propuesta fue automáticamente desechada por el Consulado de Guadalajara. Adoptando un discurso proteccionista, sostenían que los bienes asiáticos generaban serios inconvenientes para el desarrollo de las producciones y

\footnotetext{
${ }^{17}$ Es un rico e interesante acervo documental que poco se ha trabajado. Nos será de suma utilidad en las siguientes páginas.

${ }^{18}$ Real Audiencia. Instituciones coloniales, Consulado, vol. 193, exp. 5, f. 121. AGN.
} 
manufacturas locales. Pero desde Filipinas apuntaban, no sin cierta ironía, cómo era posible sostener ese argumento con "la entrada frecuentísima de buques panameños que le llevan en tanta abundancia no sólo efectos extranjeros de algodón inglés, sino de todas clases que perjudican la industria de aquel reino". ${ }^{19}$

La posición sostenida desde el archipiélago oriental tenía mucho de cierto. Al menos desde los años iniciales del siglo XIX una corriente de barcos panameños llegaba a San Blas con textiles ingleses para su distribución y consumo no sólo por Tepic y ciudad de Guadalajara, sino también por el norte californiano. Desde su fundación (1795) el Consulado de Guadalajara había empezado a controlar la circulación de mercancías por zonas aledañas y territorios norteños; cuestionando y evitando la mediación del Consulado de la ciudad de México. Más que un fomento al desarrollo interno, el comercio de Guadalajara priorizaba las importaciones británicas de bajo costo enviadas por "arrieros panameños" que los bienes asiáticos venidos desde Filipinas o Cantón. Hacia 1815, el Consulado de la ciudad de México denunciaba que entre 1811 y 1814 visitaron el puerto de San Blas 25 buques procedentes de Lima, Panamá, Guayaquil, Acapulco, Sonsonate y "otros puertos de la costa de la costa meridional del Sur". ${ }^{20} \mathrm{Al}$ examinar sus pólizas se llegaba a la conclusión que "los cargamentos que asombran y valen millones son: tejidos de algodón y extranjeros, como cotonías, sarasas, panas, casimiras [sic], rengues, irlandas [sic], estopillas, medias, pañuelos de Madras, percales, etc..".

Estos productos se pagaban fundamentalmente en plata y oro. El drenaje de metálico que antes se concentraba en su mayor parte con destino a China, vía Acapulco-Filipinas, ahora era concentrado por los británicos. Aquí vemos un ejemplo claro de cómo el eje ciudad de México-Acapulco se veía desplazado por el entronque San Blas-Panamá; una transformación que tuvo grandes costos para el Consulado de la ciudad de México (Trejo, 2006b).

Si bien desde principios del siglo XIX comenzaban a llegar barcos panameños hacia San Blas con cargamentos de tejidos de algodón inglés, recién para el año 1809 se llega a conocer la magnitud que tuvo el fenómeno. En una situación de desabasto y ante la imposibilidad de hacer llegar los bienes por vía terrestre dada las luchas por la independencia, Panamá dispuso desde entonces con permisos reales para reexpedir mercancía ex-

${ }^{19}$ Representación del apoderado del Consulado de Manila, quejándose del diferente trato que recibían las naos de filipinas respecto a los barcos de Panamá. Véase Cabañas (1944, p. 171).

${ }^{20}$ Sobre el recurso hecho al rey contra el comercio de efectos extranjeros que se hace por Panamá a San Blas y puertos de Tampico y Tuxpan. Véase Cabañas (1944, pp. 75-76).

${ }^{21}$ Sobre el recurso hecho al Rey contra el comercio de efectos extranjeros que se hace por Panamá a San Blas y puertos de Tampico y Tuxpan. Véase Cabañas (1944, p. 75). 
tranjera hacia San Blas. La autorización que benefició a Guadalajara no sólo atacaba los intereses de los comerciantes de la ciudad de México, sino también a la corporación mercantil de Veracruz que vio disminuir desde 1809 su función de acopio y redistribuidor de textiles británicos hacia el espacio novohispano (Trejo, 2006b, pp. 718-720).

Los textiles ingleses llegaban a través de pequeñas fragatas, coletas o bergantines cuyos propietarios eran los comerciantes locales panameños. Para los centroamericanos resultó un negocio muy rentable establecer redes con las casas comerciales y agentes ingleses que operaban desde Jamaica (Valdés, 1987, pp. 255-256). En los primeros años que se desarrolló este comercio, no encontramos ni barcos ni capitanes ingleses. El comercio de textiles de procedencia inglesa vía Panamá hacia San Blas se realizó, en un principio, con navíos y agentes centroamericanos, particularmente panameños. A partir de 1820 podemos identificar la llegada de comerciantes y barcos ingleses por San Blas (véase cuadro 1).

Nuestro listado estaría incompleto. Pardo (1994, pp. 88-90) identificó algunos navíos panameños en San Blas desde 1810 con productos asiáticos e ingleses para el mercado de Guadalajara, el Occidente y el Septentrión. Segundo, sabemos que tan sólo en cinco años (entre 1812 y 1817) habrían ingresado por Tepic 55000000 de pesos en manufacturas inglesas. ${ }^{22}$ Además, el apoderado del comercio de Manila señalaba que sólo en 1817 habían fondeado 35 naves panameñas y quince más en las primera mitad de 1818, cuando en nuestro cuadro sólo pudimos registrar dos embarcaciones para 1817 y ninguna para el siguiente. La corriente sistemática de embarcaciones panameñas en San Blas muestra la bienvenida al tejido inglés desde Guadalajara; un rubro que comenzaba a suplantar el consumo de los tejidos asiáticos. Era evidente el trato desigual que recibían en San Blas ambos flujos de comercio. Con cierta desesperación con el objetivo de reimpulsar el comercio asiático con México, el Consulado de Manila propuso en 1813 dar por terminado la vida del Galeón de Manila reemplazándolo por buques particulares, algo que tendrá cierto éxito años después. ${ }^{23}$ Lo cierto es que el galeón ya no podía competir con el comercio inglés practicado desde Panamá. Hacia 1815, cuando fondeaba en San Blas la nao Magallanes, el último Galeón de Manila, su "miserable" cargamento sufrió por parte de los funcionarios de aduana de San Blas un rígido control, hasta el punto de ser comisado. Mientras tanto, los buques de Panamá eran "recibidos en clase de amigos", ingresando "algodón, ya con el nombre de

\footnotetext{
${ }^{22}$ Representación del apoderado del Consulado de Manila quejándose del diferente trato que recibían las naos de Filipinas respecto de los barcos de Panamá. Véase Cabañas (1944, p. 168).

${ }^{23}$ Estado. Propuesta para sustituir la Nao de China por buques particulares. Cádiz, $13 \mathrm{de}$ marzo de 1813,86 A, N. 28. AGI.
} 


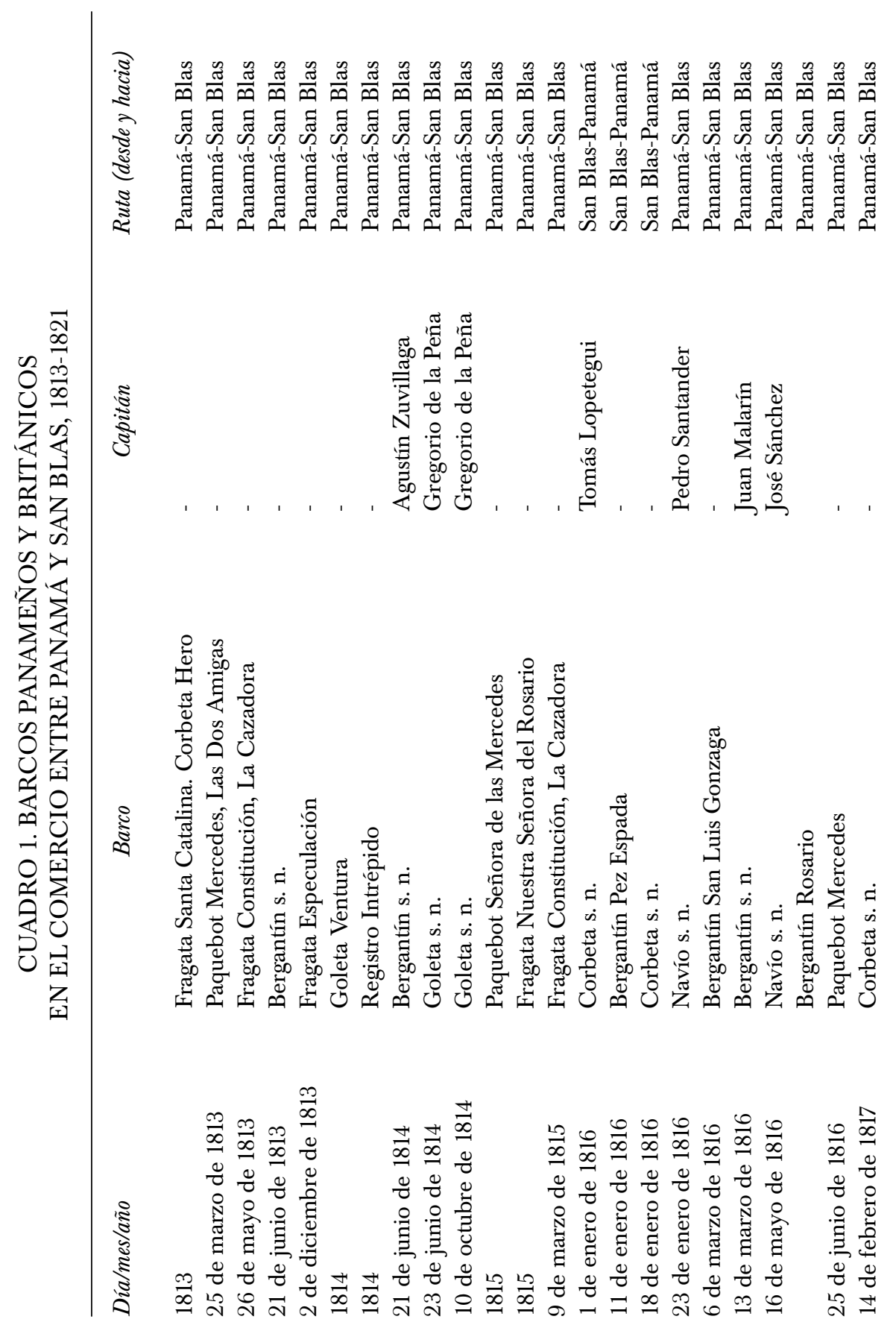




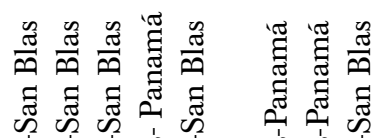

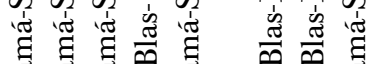

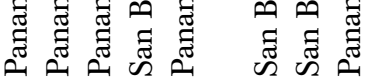
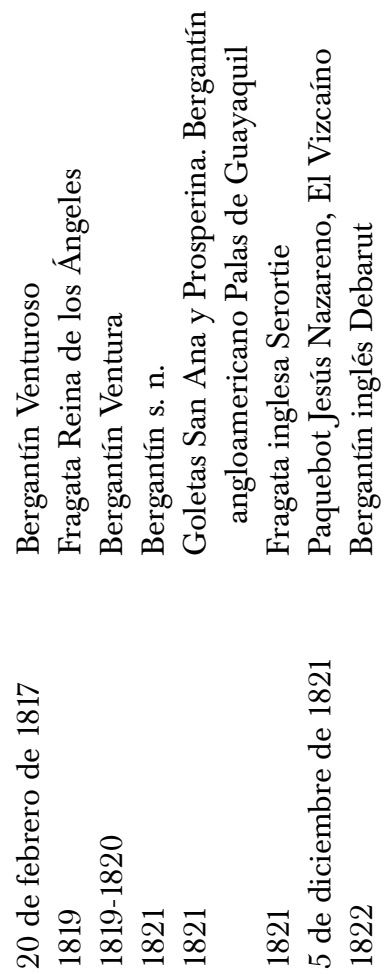

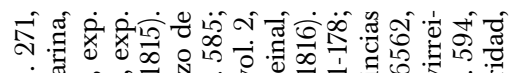

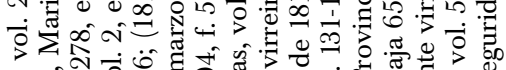

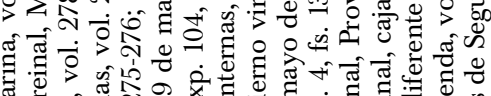
ส

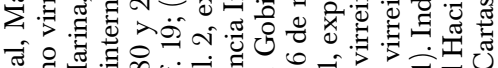

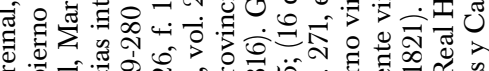

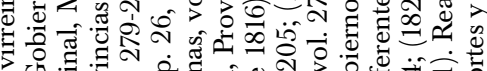

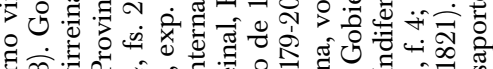

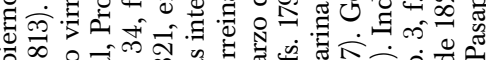

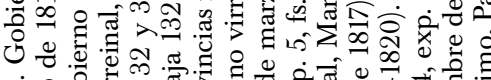

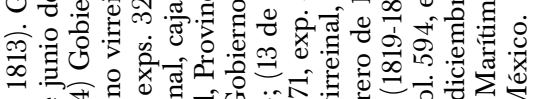

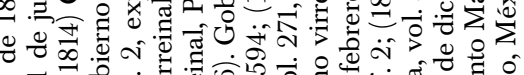

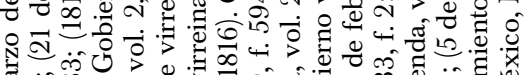

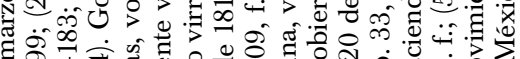

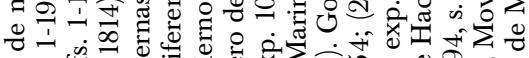
L ڤ A . :

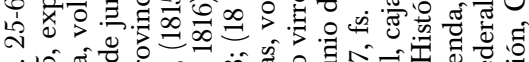
wis

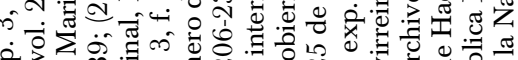

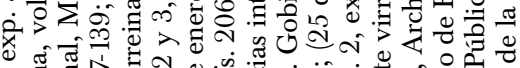

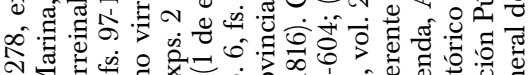

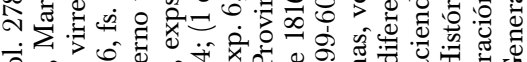

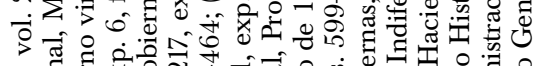

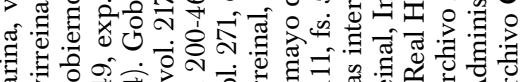

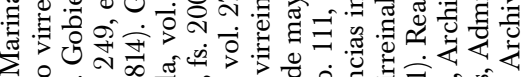

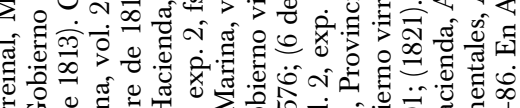

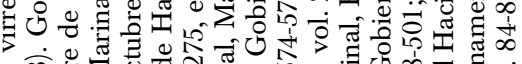

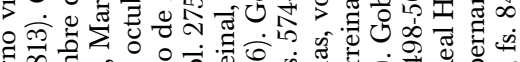

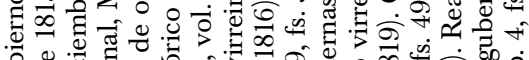

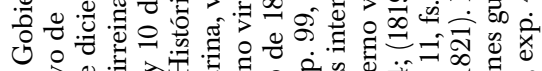

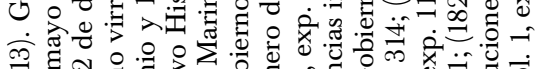

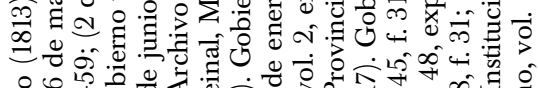
$8 \%$

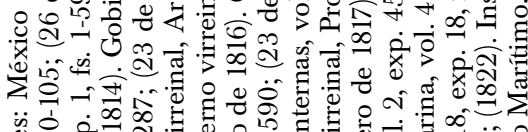

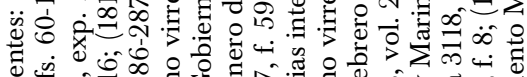

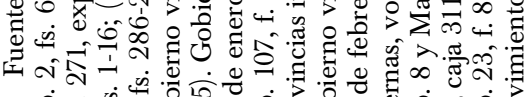

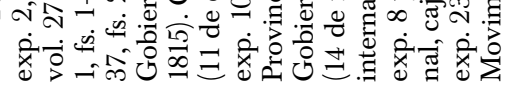


mantas lavadas, ya con el nombre propio de sanas, garras, bafetas, sarampures y elefantes, permitidos exclusivamente al comercio de filipinas". ${ }^{24}$

El comercio británico se "había naturalizado" entre los comerciantes de Guadalajara, hasta el punto de provocar no sólo el descenso del comercio directo entre México y China, sino también grandes pérdidas a la Real Compañía de Filipinas, que se mantenía en funcionamiento gracias a los privilegios de exención de impuestos y de inyección de capitales otorgados por el poder peninsular. ${ }^{25}$

Ahora bien, el concepto de segunda atlantización del Pacífico para el caso del comercio entre Panamá y San Blas no sólo tiene sentido cuando nos referimos a los cambios de orientación de las rutas comerciales, sino también al identificar la procedencia de los bienes asiáticos que llegaban al mercado mexicano. En efecto, las mercaderías del oriente, las que durante el funcionamiento del lago indiano estuvieron monopolizadas por el Galeón de Manila, ahora se veían movilizadas por los barcos panameños, gracias a su acopio en Jamaica. Las mercancías asiáticas llegaban con mayor rapidez al mercado de Guadalajara y con un costo mucho más bajo que la transportada legalmente por el Galeón de Manila y otras embarcaciones que hacían la ruta directa desde las islas Filipinas. El comercio de contrabando que hacían los barcos panameños hacia San Blas con tejidos asiáticos y algodones ingleses evitaba $42 \%$ de los derechos que pesaban a toda embarcación procedente del archipiélago oriental. Hacia 1815, el comercio de Manila decía lo siguiente:

Las expediciones de Manila se fundan en la demanda que de los efectos asiáticos que importan suponen en este continente, esa demanda se satisface con desmedida abundancia por los barcos panameños que han atestado el Reino de estos artículos; luego son inútiles aquellas expediciones pues traen lo que ya no se necesita. Por otra parte, los cargamentos de Manila pagan en la actualidad, como por separado he hecho presente cerca de cuarenta y dos por ciento; y a proporción de estos gravámenes regulan el valor de sus ventas; mientras que los ingleses por medio de los panameños ni satisfacen derechos, reglamentados ni provinciales, sino con la escasez que está a su arbitrio, y dan sus géneros a precios incomparablemente más bajos que los filipinos; con que los consumidores que sólo cuidan de su momentánea comodidad, en un tiempo que todo ahorro es tan necesario como

${ }^{24}$ Representación del apoderado del Consulado de Manila quejándose del diferente trato que recibían las naos de Filipinas respecto de los barcos de Panamá. Véase Cabañas (1944, pp. 166-167).

${ }^{25}$ Representación del apoderado del Consulado de Manila quejándose del diferente trato que recibían las naos de Filipinas respecto de los barcos de Panamá. Véase Cabañas (1944, p. 179). 
conveniente, se dan prisa a surtirse de los panameños, y abandonan a la polilla y podredumbre los efectos de Manila. ¿Podrá subsistir este desgraciado comercio ${ }^{26}$

Es evidente que no pudo subsistir el Galeón de Manila, ni el comercio directo entre México con Asia. Estamos en presencia de la debacle de un elemento fundamental que daba sentido al comercio entre el oriente e Hispanoamérica por el lago indiano. Las relaciones con Asia entraron a una fase de decadencia y se iniciaba una nueva era globalizadora, dirigida por la economía británica y su flamante revolución industrial.

Sin duda, lo que aquí hemos analizado es la antesala del proceso de consolidación del comercio inglés por el Pacífico mexicano. Desde 1790 hasta 1820 las navegaciones británicas vía Cabo de Hornos o realizadas como punto de partida desde Panamá establecieron las condiciones para el asentamiento definitivo de agentes y compañías inglesas en la economía mexicana. Sin duda, el caso más emblemático es la fundación en 1830 de la compañía Barron and Forbes en San Bla, una institución que tuvo significativo peso económico y político no sólo en el Pacífico mexicano, sino en las relaciones económicas y diplomáticas entre Inglaterra con el flamante Estado mexicano. El propio Eustaquio Barron alcanzó el cargo de cónsul británico en México mientras realizaba su actividad empresarial (Mayo, 1991, pp. 673-696). Pero el caso supera el marco temporal del presente ensayo y merecería un estudio independiente.

\section{Conclusiones: del Pacífico indiano al Pacífico extranjero}

En el primer apartado, demostramos que el lago indiano sólo pudo ser posible bajo el régimen de monopolio comercial que instauró la monarquía de los Austrias y de los primeros borbones. Si bien logró constituirse en un espacio marítimo con marcada autonomía y de una notable libertad para el accionar de los agentes mercantiles de la ciudad de México y de Perú, habría que reconocer que ese mundo marítimo habría encontrado su razón de ser dentro del marco del monopolio que diseñó España para las relaciones económicas con Hispanoamérica a través del Atlántico. En otros términos, para que la ciudad de México lograra convertirse en el principal almacén continental de bienes extranjeros y se establezca como una de las principales fuentes de abasto del mercado del virreinato de Perú, fue necesario que los más importantes mercaderes de la ciudad de México y de Lima dispusieran de la facultad monopólica en su más amplio sentido: ex-

\footnotetext{
${ }^{26}$ Representación del apoderado del Consulado de Manila quejándose del diferente trato que recibían las naos de Filipinas respecto de los barcos de Panamá. Véase Cabañas (1944, p. 170).
} 
clusividad de puertos, rutas y monopolio en la importación de mercancías y exportación de plata. Las reformas comerciales implementadas durante la segunda parte del siglo XVIII, desarticularon el lago indiano, en tanto el área marítima bajo el control de capitales novohispanos y peruanos. Propusimos que los principales factores que llevaron a su desmoronamiento habrían sido tres: a) la aparición de agentes, capitales e instituciones mercantiles peninsulares por el Pacífico, en un contexto de mayor libertad comercial y portuaria; $b$ ) la apertura implementada hacia 1740 por España para las navegaciones comerciales por el Cabo de Hornos desde el Atlántico hacia el Pacífico sudamericano, y $c$ ) el contrabando de textiles asiáticos e ingleses promovido a principios del siglo XIX por las casas comerciales inglesas instaladas en Jamaica en el trayecto de Panamá hacia San Blas.

Los factores reseñados reflejan, ante todo, el gran fenómeno de la "atlantización” del Pacífico. El concepto que ofrecemos daría cuenta de la intromisión y hegemonía de barcos, agentes, bienes y circuitos promovidos desde España-Europa sobre un área marítima de circulación naval que previamente se encontraba distante y ajena a los intereses de la economía atlántica-europea. El nacimiento del trayecto por el Cabo de Hornos para las navegaciones de los navíos de registro permitió que los comerciantes españoles les arrebatasen a los comerciantes de la ciudad de México el mercado consumidor de Sudamérica, en tanto agentes de abastecimiento de productos europeos. De tal manera, el Pacífico de las últimas décadas del siglo XVIII no podría definirse como un lago indiano. La decadencia del Galeón de Manila fue una expresión directa de la erosión que sufrió el Consulado de la ciudad de México, particularmente en su facultad monopólica de importación de bienes y salidas de plata por el eje transpacífico. El concepto Spanish Lake, término que gran parte de la historiografía adoptó para el Pacífico, parecería ser, de ahora en más, la identidad más adecuada. Las compañías comerciales españolas incursionarán en las aguas del Pacífico con capitales, agentes y derroteros alternativos, cuestionando el control de los más reconocidos mercaderes indianos sobre el galeón asiático y el comercio entre México y Perú por el Mar del Sur. Pero aquel lago español habría tenido una vida bastante breve, comprendida entre 1750 y 1790 . Hacia fines del siglo, los ingleses y, en menor medida, los angloamericanos emprendieron un dominio de los intercambios, construyendo una identidad del área más cercana a la de un "Pacífico extranjero".

El despojo y la extranjerización del Pacífico sudamericano y mexicano se habrían profundizado a partir de la última década del siglo XIX, con la venta de textiles de algodón ingleses y asiáticos por parte de las embarcaciones balleneras británicas y angloamericanas. Por su parte, el contrabando inglés de textiles asiáticos e ingleses desde Panamá hacia San Blas representó una segunda instancia de extranjerización del Pacífico, en 
este caso, del Pacífico mexicano. De tal manera, la unidad indiana del Pacífico sufrió una fuerte fragmentación desde el Atlántico europeo a través de dos vías de comunicación transoceánicas: Cabo de Hornos y Panamá. Esto no implica sostener que las conexiones entre México y los puertos de Ecuador, Perú y Chile se hayan paralizado. Más bien, vemos que las movilizaciones de barcos locales entre ambas áreas se sujetaron al dominio de capitales y agentes ingleses. En definitiva, el Pacífico hispanoamericano, que desde 1580 logró constituirse como una unidad espacial plenamente americana desde Chile hasta México, terminará por convertirse, desde las reformas borbónicas hasta el periodo de las emancipaciones de los Estados iberoamericanos, en un océano fragmentado, dependiente y sujeto a la economía inglesa.

\section{LISTA DE REFERENCIAS}

Abreu, A. (1977). Extracto historial del comercio entre China, Filipinas y Nueva España (1736) (t. II, ed. Carmen Yuste). México: Instituto Mexicano de Comercio Exterior.

Alfonso, M. y Martínez, C. (2013). La ruta del Cabo y el comercio español con Filipinas. En S. BERnABEU y C. MARTínez, Un océano de seda y plata: el universo económico del Galeón de Manila (pp. 307-340). Sevilla: Consejo Superior de Investigaciones Científicas/Escuela Española de Historia y Arqueología en Roma.

ÁlVAREZ, L. (2007). El impacto de las reformas borbónicas en las redes comerciales. Una visión desde el Pacífico hispano, 1762-1815. En A. IBARRA y G. DEL VALLE, Redes sociales e instituciones comerciales en el imperio español, siglos XVII a XIX (pp. 187213). México: Instituto de Investigaciones Dr. José María Luis Mora/Universidad Nacional Autónoma de México.

Bernabeu, S. (1992). El Pacífico ilustrado: del lago español a las grandes expediciones. Madrid: Mapfre.

Bonialian, M. (2012). El Pacífico hispanoamericano. Política y comercio asiático en el imperio español (1680-1784). La centralidad de lo marginal. México: El Colegio de México.

Bonialian, M. (2014). China en la América colonial. Bienes, mercados, comercio y cultura del consumo desde México hasta Buenos Aires. México: Instituto de Investigaciones Dr. José María Luis Mora.

BorJa, D. y NAGY, Á. (1964). El comercio de cacao de Guayaquil. Revista de Historia de América, 57/58, 1-50.

Cabañas, R. (1944). Comercio extranjero por el puerto de San Blas en los años 1812 a 1817. México: Secretaría de Hacienda y Crédito Público.

CÁrdenas, E. (1968). San Blas de Nayarit (vol. I). México: Secretaría de Marina.

CARmagnani, M. (2000). Los mecanismos de la vida económica en una sociedad colonial. Chile (1680-1830). Santiago de Chile: Dirección de Bibliotecas, Archivos y Museos/ Centro Barros Arana. 
CONTRERAs, C. (1990). El sector exportador de una economía colonial: la costa del Ecuador entre 1760 y 1820. Quito: Facultad Latinoamericana de Ciencias Sociales.

Cross, H. (1983). South American bullion production and export 1550-1750. En J. Richards (ed.), Precious metals in the later medieval and early modern world (pp. 397423). Durham: Carolina Academic Press.

Cruz, S. (1962). La Nao de China. México: Jus.

Díaz-Trechuelo, M. (1965). La Real Compañía de Filipinas. Sevilla: Escuela de Estudios Hispanoamericanos/Consejo Superior de Investigaciones Científicas.

FLYNN, D. y GiRÁldeZ, A. (2014). Los orígenes de la globalización en el siglo XVI. En B. Hausberger y A. Ibarra (coords.), Oro y plata en los inicios de la economía global: de las minas a la moneda (pp. 29-76). México: El Colegio de México.

FLORES, R. (2010). Los balleneros anglo-norteamericanos y la apertura comercial del Pacífico sur a fines de la época colonial (1790-1820). Historica, 34(2), 63-98.

Hang-Sheng, CH. (1997). Trade between China, the Philippines and the Americas during the sixteenth and seventeenth centuries. En D. Flynn y A. Giráldez (coords.), Metals and monies in an emerging global economy (pp. 845-853). Hampshire: Variorum.

Hamerly, M. (1973). Historia social y económica de la Antigua Provincia de Guayaquil. Guayaquil: Publicaciones del Archivo Histórico de Guayas.

Hoberman, L. (1991). Mexico's merchant élite, 1590-1660. Silver, state and society. Durham: Duke University Press.

IbarRA, A. (2000). Mercado urbano y mercado regional en la Guadalajara colonial, 1770-1810 (Tesis doctoral). El Colegio de México, México.

Lamikiz, X. (2010). Trade and trust in the eighteenth-century Atlantic world, Spanish merchants and their overseas networks. Gran Bretaña: The Royal Historical Society/The Boydell Press.

LeÓn, J. (2001). 3. Comercio por el Mar del Sur o Pacífico, 1790-1800 (Mapa 4). Revista de Historia, 43, 318-347.

MAYO, J. (1991). Imperialismo de libre comercio e imperio informal en la costa oeste de México durante la época de Santa Anna (Traducción de Mario Zamudio Vega). Historia Mexicana, 40(4), 673-696.

McMaster, J. (1959). Aventuras asiáticas del peso mexicano. Historia Mexicana, 8(3), 372-399.

MEjÍA, J. (septiembre, 2011). Una interpretación neoclásica del fin del Galeón de Manila. Contribuciones a la Economía. Recuperado de: https://www.academia. edu/1030495/Una_interpretaci $\%$ C3\%B3n_neocl $\%$ C3\%A1sica_del_fin_del_ Gale $\%$ C3\%B3n_de_Manila

Meyer, J. (2008). Breve historia de Nayarit, Breve historia de los Estados. México: El Colegio de México/Fideicomiso Historia de las Américas.

Miño, M. (2013). El cacao guayaquil en Nueva España, 1774-1812 (política imperial, mercado y consumo). México: El Colegio de México. 
MonsÉGur, J. DE (1994). Las nuevas memorias del capitán Jean de Monségur. México: Universidad Nacional Autónoma de México.

Moutoukias, Z. (1988). Contrabando y control colonial en el siglo XVII: Buenos Aires, el Atlántico y el espacio peruano. Buenos Aires: Centro Editor de América Latina.

NAKAmurA, Y. (2007). Importación y la demanda de bienes importados de Nueva España, 1767-1810 (Tesis doctoral). El Colegio de México, México.

NAVARro, L. (1965). El comercio interamericano por la Mar del Sur en la edad moderna. Revista de Historia, 23, 11-55.

PARdo, C. (1994). San Blas y su relación con Filipinas, 1790-1820. México: Universidad Autónoma Metropolitana.

Parrón, C. (1995). De las reformas borbónicas a la república: El Consulado y el comercio marítimo de Lima, 1778-1821. Murcia: Academia General del Aire.

PeArCe, A. J. (2007). British trade with Spanish America, 1763-1808 (vol. 9). Gran Bretaña: Liverpool University Press.

Pereira, E. (1971). Los primeros contactos entre Chile y los Estados Unidos 1778-1809. Santiago: Andrés Bello.

Romano, R. (1998). Moneda, seudomonedas y circulación monetaria en las economías de México. México: El Colegio de México.

Ruiz, J. (1976). La casa de Ustáriz, San Ginés y compañía. En La burguesía mercantil gaditana (1650-1868), ponencias presentadas en el XXXI Congreso Luso-Español para el Progreso de las Ciencias (pp. 183-197). Cádiz: Instituto de Estudios Gaditanos.

RuIz, J. (1985). Intento gaditano de romper el monopolio comercial novohispanofilipino. En Andalucía y América en el siglo XVIII, Actas de las IVJornadas de Andalucía y América (pp. 147-179). Sevilla: Escuela de Estudios Hispanoamericanos.

Schurz, W. L. (1922). The spanish lake. Hispanic American Historical Reviere, 5(2), 181-194.

Spate, O. (1979). The spanish lake: The Pacific since Magellan (vol. 1). Minesota: Minessota University Press.

SuÁRez, M. (2001). Desafíos transatlánticos: mercaderes, banqueros y el estado en el Perú virreinal, 1600-1700 (vol. 194). Lima: Fondo de Cultura Económica.

Trejo, D. (2006a). El puerto de San Blas, el contrabando y el inicio de la internacionalización del comercio en el Pacífico noroeste. Tzintzun. Revista de Estudios Históricos, 44, 11-48.

Trejo, D. (2006b). Implicaciones del comercio por el puerto de San Blas durante la guerra de Independencia. Revista de Indias, 66(238), 711-736.

UlloA, A. (1953). Noticias secretas de América (1747). Buenos Aires: Mar Océano.

VALdÉs, V. (1987). De las minas al mar. Historia de la plata mexicana en Asia, 1565-1834. México: Fondo de Cultura Económica.

VAlle, G. (2010). Comercialización del cacao de Guayaquil por los mercaderes de la ciudad de México en la segunda mitad del siglo XVIII. Méxican Studies/Estudios Mexicanos, 26(2), 181-206. 
Vila-Vilar, E. (1982). Las ferias de Portobelo: apariencia y realidad del comercio con Indias. Anuario de Estudios Americanos, 39, 275-340.

Villalobos, S. (1962). El comercio extranjero a fines de la dominación española. Journal of Inter-American Studies, 4(4), 517-544.

Villalobos, S. (1965). Comercio y contrabando en el Río de La Plata y Chile, 1700-1811 (vol. 32). Buenos Aires: Universidad de Buenos Aires.

Yuste, C. (1984). El comercio de la Nueva España con Filipinas, 1590-1785. México: Instituto Nacional de Antropología e Historia.

YUSTE, C. (2000). El eje comercial transpacífico en el siglo XVIII: la disolución imperial de una alternativa colonial. En C. YUSTE y M. SouTO (coords.), El comercio exterior de México, 1713-1850. Entre la quiebra del sistema imperial y el surgimiento de una nación (pp. 21-41). México: Instituto de Investigaciones Dr. José María Luis Mora/Universidad Nacional Autónoma de México/Universidad Veracruzana.

Yuste, C. (2007). Emporios transpacíficos. Comerciantes mexicanos en Manila, 1710-1815. México: Universidad Nacional Autónoma de México.

Archivos

AGI Archivo General de Indias, Sevilla, España.

AGN Archivo General de la Nación, Ciudad de México, México. 